\title{
Clinical practice guidelines for managing coagulation in patients undergoing endoscopic procedures
}

\author{
F. Alberca-de-las-Parras \\ Service of Digestive Diseases. Hospital Virgen de la Arrixaca. Murcia, Spain
}

Alberca-de-las-Parras F. Clinical practice guidelines for managing coagulation in patients undergoing endoscopic procedures. Rev Esp Enferm Dig 2010; 102: 124-138.

\section{WHY IS THERE A NEED TO CREATE GUIDELINES RELATED TO PROBLEMS IN COAGULATION AND CONDUCTING ENDOSCOPIC PROCEDURES?}

For many years, anti-coagulants and single or double anti-platelet agents have become a therapeutic and preventative arm particularly in high-prevalence cardiovascular pathologies. This fact, combined with the increase in endoscopic techniques suggests an increased risk.

However, the risk is not only a precursor to potential haemorrhage, but to a potential risk of thrombosis (1) as well, hence the endoscopists should not overlook these possible risks.

An effort must be made to jointly collect criteria based on published scientific literature. Other associations have already initiated efforts towards accomplishing this task (2-4) and secondary benefits have even been demonstrated in both cost-effectiveness as well as having zero impact on the incidents of thrombosis in implementing these guidelines (5).

Received: 09-02-09.

Accepted: 17-02-09.

Correspondence: Fernando Alberca de las Parras. Servicio de Aparato Digestivo. Hospital Virgen de la Arrixaca. Ctra. Madrid-Cartagena, s/n. 30120 El Palmar, Murcia.e-mail: f_alberca@yahoo.es

\section{WHAT ATTITUDE SHOULD BE TAKEN WHEN FACED WITH THE UTILIZATION OF ANTICOAGULANTS, ANTI-PLATELET AGENTS OR NSAIDS IN PATIENTS WITH GASTROINTESTINAL HAEMORRHAGE? (Fig. 1)}

Anticoagulants must be discontinued immediately and the following therapeutic measures can be initiated in a sequential manner and concurrently with endoscopic techniques $(3,6)$.

1. Vitamin Kl, i.v. (phytomenadione), $10 \mathrm{mg}$ (one ampoule) mixed in $100 \mathrm{ml}$ of $0.9 \%$ normal saline or $5 \%$ glucose solution: $10 \mathrm{ml}$ over 10 minutes $(1 \mathrm{mg} / 10 \mathrm{~min})$ and afterwards, the remaining solution over 30 minutes. Its effect is not immediate and lasts over approximately 8 hours.

2. Fresh frozen plasma, 10 to $30 \mathrm{ml} / \mathrm{kg}$; at 6 hours, half the dose can be repeated as the half-life of the factors is 5 to 8 hours.

3. Prothrombin complex concentrate combined with factor IX (Prothromplex Immuno TIM 4600 I.U ${ }^{\circledR}$ ): Equivalent to $500 \mathrm{ml}$ of plasma. Dosage: (required-obtained prothrombin time) $\mathrm{x}$ weight in $\mathrm{kg}$ x 0.6 .

4. Activated recombinant factor VII: $80 \mu \mathrm{g} / \mathrm{kg}$ per slow i.v. bolus $(2 \mathrm{ml} \mathrm{amp}=1.2 \mathrm{mg})$.

- Effect takes place within 10 to 30 minutes after administration.

- The effect lasts up to 12 hours.

- It should not be combined with prothrombin complexes.

- It adjusts prothrombin time and corrects platelet function defects.

These mechanisms will be utilised until the INR stabilizes between 1.5 and 2.5 and the bleeding stops. Anticoagulants are resumed 3-5 days later once we have ensured that the risks have diminished (performed a second-look endoscopy).

Recently, an abstract was presented which demonstrated that the risk of bleeding in patients who are pre- 


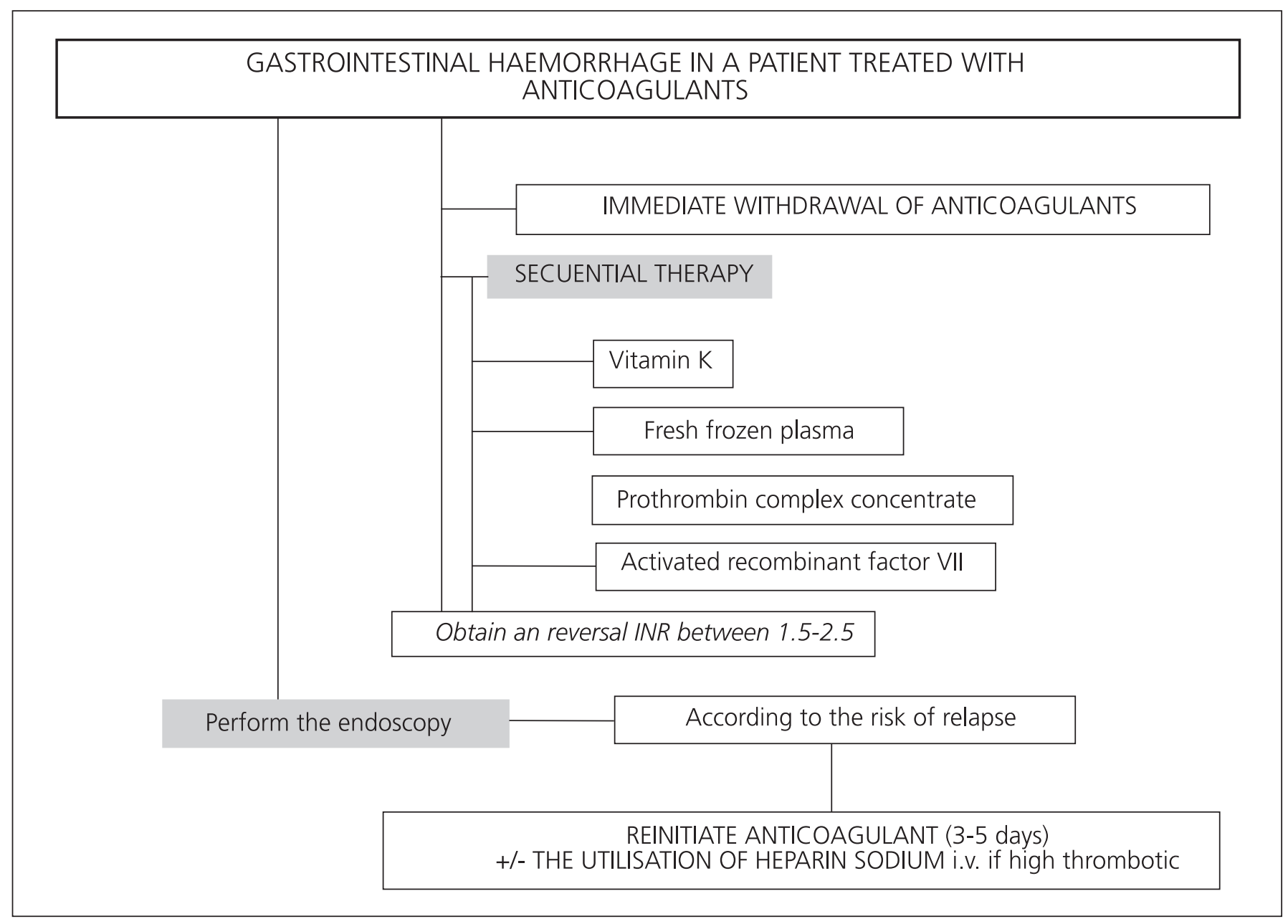

Fig. 1.

scribed anticoagulants is 6.5 times higher than in those who do not take these medications (7).

Suspending anti-platelet agents and NSAIDs does not alter the natural course of the process because its effect on coagulation will only be delayed for a few days, although it must be taken into consideration if the case consists of lesions that will not foreseeable heal quickly. Remember that aspirin and NSAIDs can be the cause itself of haemorrhage.

\section{SHOULD COAGULATION STUDIES BE CARRIED OUT BEFORE PERFORMING ENDOSCOPIC PROCEDURES?}

There is no scientific evidence available to support this action. In a clinical guide published by the American Society for Gastrointestinal Endoscopy (ASGE) (8), it was established that laboratory tests to detect unmanifested coagulation disorders was unuseful even for high-risk techniques, and is not indicated for routine pre-endoscopy testing. Furthermore, it raises legal questions regarding whether tests should be performed when a wrong interpretation of coagulation studies may lead to legal entanglements. Tests are never a substitute for a prior clinical history, and is only required if a disorder is suspected.

\section{WHAT COAGULATION DISORDERS MUST BE TAKEN INTO CONSIDERATION BEFORE PERFORMING ENDOSCOPIC PROCEDURES?}

For patients presenting with thrombocytopenia, the action to be taken depends upon the type of procedure.

- In high-risk procedures, platelet count must be higher than $50,000 / \mu 1$.

- Low-risk endoscopic explorations may be carried out in patients with a platelet count $>20,000 / \mu 1$.

\section{Recommendation $D$}

- Prothrombin activity: PT plasma levels less than $50 \%$ vs. INR $>1.5$ suggests an increased risk of bleeding. The above-mentioned plasma levels are routinely found in patients with chronic hepatopathies and in those undergoing oral anticoagulant treatment (Table I). 
- Alteration in activated partial thromboplastin time (APTT): it is considered a prolonged APTT with respect to normal APTT. This can be seen in the utilisation of heparin sodium IV.

Table I

\begin{tabular}{llll}
\hline Agent & $\begin{array}{l}\text { Haemostasis } \\
\text { stabilisation }\end{array}$ & PT/INR & APTT \\
\hline Anti-platelets & $2-10$ days* & Normal & Normal \\
NSAIDs* & $1-3$ days & Normal & Normal \\
Heparin sodium i.v. & $2-4$ hours & Prolonged $(+)$ & Prolonged $(+++)$ \\
LMW heparin & At least 12 hours & Normal & Normal \\
Oral anticoagulants & $4-6$ days & Prolonged $(+++)$ & Prolonged $(+)$ \\
\hline
\end{tabular}

*See page $4 ; * *$ See page 4

\section{HOW CAN THESE DISORDERS BE CORRECTED BEFORE PERFORMING ENDOSCOPIC PROCEDURES?}

- Correcting platelet deficiency is carried out in a programmed manner by infusion during the course of the endoscopic procedure and in the immediate prior time span. Increasing the platelet count to between 40,000 and $50,000 / \mathrm{mm}^{3}$ is all that is required.

- Each unit of platelets increases the count by 5,000 to 10,000 per $\mathrm{mm}^{3}$.

- The dosage is $1 \mathrm{U} / 10 \mathrm{~kg}$ of body weight.

- In case of platelet refractoriness with manifestations of severe bleeding, activated recombinant factor VII is recommended (rVlla) (Novoseven ${ }^{\circ}$ ), which has a hemostatic effect in patients with severe thrombocytopenia and thrombocytopathies at a dosage of 90 to $150 \mu \mathrm{g} / \mathrm{kg}$ every two hours i.v. until bleeding is controlled. Due to a high cost, its prophylactic use must be limited to very specific and urgent cases.

-In the event of alterations in prothrombin time, the same guidelines mentioned above are also applicable to patients undergoing anticoagulant therapy.

Alterations in activated partial thromboplastin time (APTT), such as in patients being treated with heparin sodium, usually revert to normal levels when medication is withdrawn within 4 to 6 hours. However, if in an emergency situation, a more rapid reversal is desired, protamine sulfate is the drug of choice; $1 \mathrm{mg}$ neutralizes 100 units of heparin. It is administered in $100 \mathrm{ml}$ of $0.9 \%$ normal saline in slow i.v. Do not administer a dose higher than $100 \mathrm{mg}$ (2 ampoules), as high doses may produce an anticoagulant effect.

\section{WHAT ENDOSCOPIC PROCEDURES ARE CONSIDERED A MAJOR RISK FOR BLEEDING?}

The risk of bleeding appears to be defined by consensus and hence different clinical guidelines and manuals were established, suggesting two risk levels (Table II):
Table II

\begin{tabular}{ll}
\hline Low risk for haemorrhage $(<1 \%)$ & High risk for haemorrhage $(\leq 6 \%)$ \\
\hline Diagnostic endoscopy with or without biopsy & Polypectomy \\
Diagnostic endoscopic retrograde & Laser coagulation and ablation \\
cholangiopancreatography (ERCP) & Sphincterotomy \\
Insertion of biliary stents without & Dilatation for benign or malignant stenosis \\
sphincterotomy & Percutaneous endoscopic gastrostomy \\
Echoendoscopy & EUS-FNA \\
Push enteroscopy & Treatment for varices \\
& Balloon enteroscopy \\
\hline
\end{tabular}

-Biopsies: the risk of haemorrhage in biopsies is approximately $1 \%$ o (9).

-Polypectomy: the risk of major haemorrhage from polypectomy in various widespread series varies between 0.05 and $1 \%$, and may even reach $4.3 \%$ in polyps larger than $1 \mathrm{~cm}$, and $6.7 \%$ in those larger than $2 \mathrm{~cm}(10-12)$. This risk seems to increase with polyps larger than $2 \mathrm{~cm}$, and pediculated polyps have been found to bleed more than sessile ones. Thus, combining the procedure with a technique that decreases the risk such as prophylactic adrenaline, an endo-loop or a single-use loop (11) is recommended for patients undergoing antiplatelet treatment.

There are two types of bleeding:

- Immediate, when nutrient vessels do not coagulate sufficiently.

- Delayed, between 1 and 14 days, but serious: It must be taken into consideration before reinitiating antiplatelet agents.

$-E R C P$ and sphincterotomy: the incidence of haemorrhage is between 2.5 and 5\% (13). Different studies define anticoagulation as a clear risk factor for bleeding. In terms of platelet antiaggregation only two retrospective studies $(14,15)$ have analysed this effect with inconclusive results as the Clinical Guidelines of the American Society suggest, yet one of them demonstrates an acute risk for bleeding (14) at $9.7 v s .3 .9 \%$ (ASA vs. control, $\mathrm{p}<0.001$ ), and for delayed bleeding at $6.5 v s .2 .7 \%(\mathrm{p}=0.04)$, which suggests that, except for emergency situations, discontinuing the medication at least 7 days before the procedure is recommended. Balloon sphincteroplasty was proposed as an alternative technique in patients requiring an emergency opening of the bile duct who had coagulation disorders (16), as well as the use of temporary biliary prostheses without sphincterotomy.

-Enteroscopy: this simple technique does not suggest any risks, but if one approaches it as a therapeutic and interventional technique, the focus must be placed on considering the procedure a risk, as in up to $64 \%$ of cases it is performed as a therapeutic measure (17).

\section{ARE SINGLE OR DOUBLE ANTIPLATELET AGENTS A CONTRAINDICATION FOR ANY ENDOSCOPIC TECHNIQUE?}

There is no convincing data that will convert single antiaggregation into an absolute contraindication for any endoscopic technique to date. 
In terms of double antiaggregation, there are no available studies about its effect, although in light of the existing data, it appears reasonable to attempt and avoid any procedures as long as this treatment is required, or low molecular weight heparin should be considered.

\section{IS THERE ANY EXISTING EVIDENCE ABOUT INCREASED INTESTINAL BLEEDING IN PATIENTS UNDERGOING ANTIPLATELET THERAPY?}

In a study in experimental animals where 7-mm lesions in the colon were induced, an increase in bleeding time was demonstrated in animals treated with aspirin versus the control group (155 vs. 169 seconds $-\mathrm{p}<0.05$ ) (18); in the same manner, an increase in bleeding at the biopsy suture site was also present in patients treated with aspirin versus NSAIDs or the control group (19).

Nevertheless, these experimental studies did not demonstrate any clinical impact on the literature when referring to its relevance in patients undergoing endoscopic procedures.

The Sociedad Española de Anestesiología y Reanimación [The Spanish Society of Anesthesiology and Recovery] have prepared joint recommendations prior to carrying out loco-regional and epidural aenesthesia with the following data $(20,21)$ (Tables III and IV):

Table III. Safety time for antiplatelet agents

\begin{tabular}{|c|c|}
\hline 10 days & Ticlopidine (Tiklid ${ }^{\bullet}$, Ticlodone ${ }^{\bullet}$, Ticlopidina EFG $\left.{ }^{\bullet}\right)$ \\
\hline 7 days & 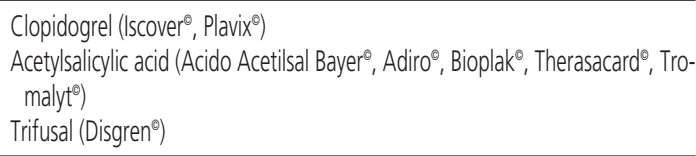 \\
\hline 1 day & $\begin{array}{l}\text { Dipiridamole (Persantin }{ }^{\bullet} \text { ) } \\
\text { Tirofiban }\left(\text { Aggrastat }{ }^{\bullet}\right)\end{array}$ \\
\hline
\end{tabular}

Table IV. Antiplatelet activity in NSAIDs

\begin{tabular}{ll}
\hline Significative (7 days) & Aspirin, Piroxicam, Tenoxicam, Indomethacin, Ketorolac, Flurbiprofen \\
\hline Wewak (12 hours) & Meloxicam, Sulindac, Nabumetone, Diflunisal, Paracetamol, Dipyrone \\
\hline None (0 days) & Coxibs \\
\hline
\end{tabular}

- Aspirin and NSAIDs have not demonstrated an increased risk of bleeding in case of in various studies that were carried out, although these studies were retrospective or limited in their analysis, and were the basis for the ASGE clinical guidelines which recommend withdrawing antiaggregants prior to endoscopic procedures $(13,22-24)$.
However, in one of the prospective studies (22), while no increase in complications is seen, it does show bleeding traces in faeces in up to $6.3 \%$ of patients versus $2.1 \%$ in the placebo group. In a study on controlled cases (25), the most important complication, which is delayed bleeding, was specifically analysed, confirming that there is no increase in bleeding whatsoever in the subgroup that took aspirin versus placebo. However, the use of aspirin beyond 3 days after the procedure was not analysed, and episodes of bleeding occurred up to 19 days after the different techniques, which raises at least questionable doubts about the analysis.

As mentioned before, there are only two studies on sphincterotomies which analyse its effect, even if they are limited in their interpretation. For this reason, some authors (26) recommend withdrawing antiplatelet agents 4 to 7 days before risky procedures, and then reinitiate these agents after 7 days when prescribed as a primary or secondary prevention measure, at 10 days after a sphincterotomy, or at 14 days following polypectomy.

In testing for high risk of bleeding, it has been determined that clopidogrel should be withdrawn 5 days in advance in patients taking double antiplatelet agents (27).

\section{WHAT PATHOLOGIES HAVE A MAJOR RISK OF THROMBOSIS BEFORE ANTIPLATELET REVERSAL?}

-Coronary stents: early suspension of double antiplatelet agents (aspirin + clopidogrel) have a 29\% (8$30 \%$ ) risk of thrombosis due to stent placement (Fig. 2):

- Non drug-eluting stents: continue for 1 month.

- Drug-eluting stents (antiproliferative release): continue for 1 year (or 18 months).

- Secondary prevention (after recent AMI): there are no increased benefits for combined ASA + clopidogrel versus clopidogrel as a single agent (28).

- Primary prevention of cardiopathy in at-risk patients: double antiplatelet therapy is not specified.

-Following hip or knee arthroplasty or surgery for hip fracture: the risk is increased at 10 to 35 days, hence LMWH or fondaparinux is recommended.

In all cases, it is preferable to delay the procedure until the thrombotic risk is at the most minimal possible; in cases of double antiplatelet therapy, it is possible to either suspend clopidogrel 7 days in advance and continue with aspirin according to established guidelines, or to provide coverage with a low molecular weight heparin.

\section{IS ANTICOAGULATION THERAPY A CONTRAINDICATION FOR ANY ENDOSCOPIC TECHNIQUE?}

- Yes, for endoscopic techniques that have a high risk of bleeding. 


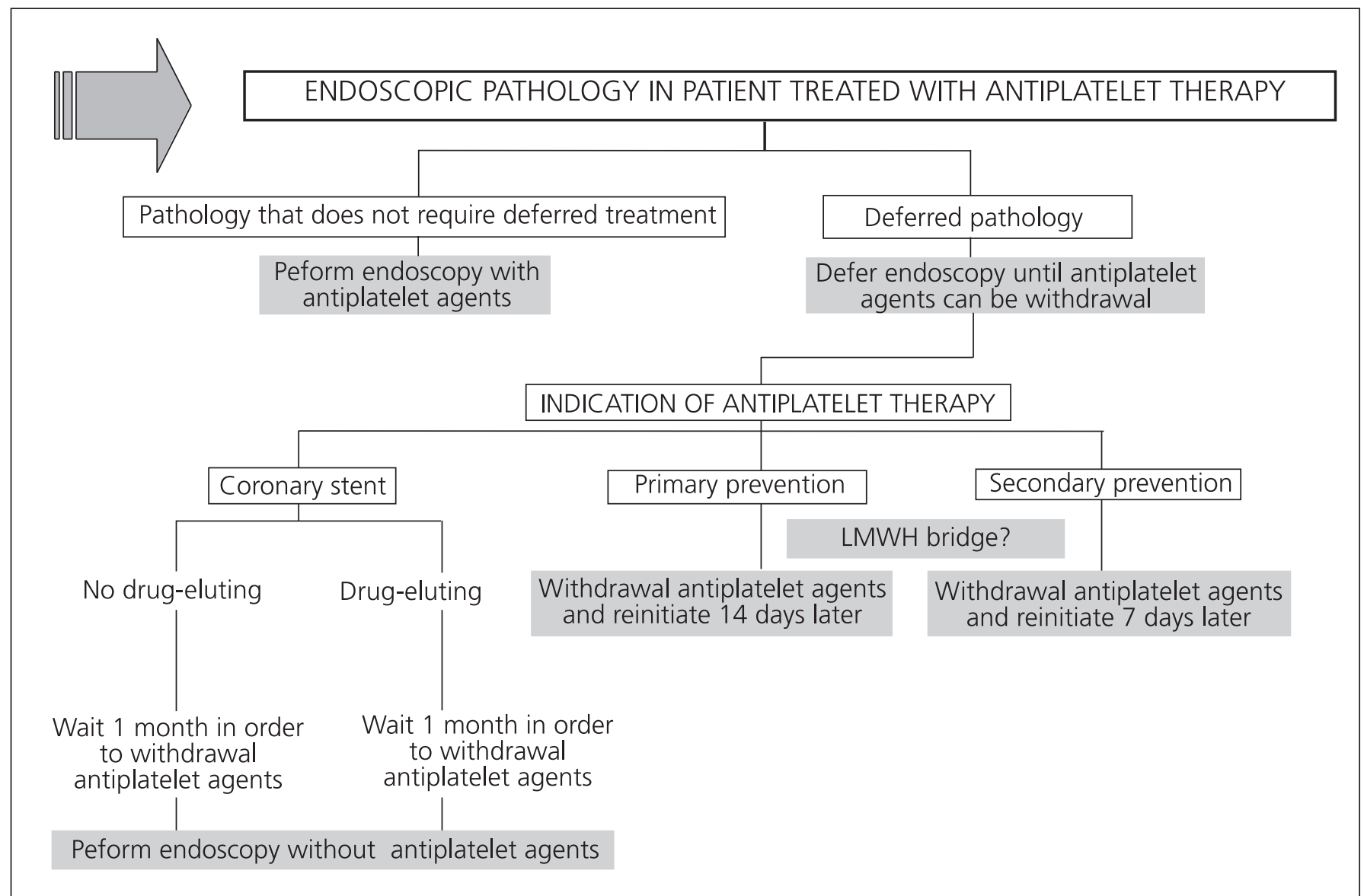

Fig. 2.

- In emergency cases, these techniques can be considered feasible after anticoagulation reversal (vitamin $\mathrm{K}$, fresh frozen plasma or prothrombin factors) until an INR $\leq 1.4$ is obtained.

\section{WHAT PATHOLOGIES HAVE A MAJOR RISK OF THROMBOSIS BEFORE ANTICOAGULATION REVERSAL?}

ASGE (2) defines the risk of thrombosis using two degrees which have been presumed to be a general rule by other authors in manuals (29) and reviews (30), as there is no refuting evidence available in the scientific literature (Table V).

\begin{tabular}{ll} 
& Table V \\
\hline $\begin{array}{l}\text { Low-risk (1-2\% if anticoagulation is } \\
\text { suspended for 4 to 7 days) }\end{array}$ & High-risk \\
\hline Deep vein thrombosis & MI R/T AF with valvular disease \\
Uncomplicated MI R/T chronic or & Mechanical mitral valve prosthesis \\
paroxysmal AF with valvular pathology & Mechanical valve with prior incidence \\
Biological valve prosthesis & of thrombosis \\
Mechanical valve prosthesis & \\
\hline
\end{tabular}

\section{WHAT IS THE CLINICAL PRACTICE GUIDELINE FOR ANTICOAGULATION REVERSAL? (Fig. 3)}

In a decision-making analysis based on the implementation of ASGE5 clinical guidelines, the most cost-effective strategies were defined as follows:

- In patients with low thrombotic risk (i.e. atrial fibrillation without valvular pathology) or if the likelihood of polypectomy exceeds $60 \%$, stop warfarin 5 days in advance.

- In terms of screening colonoscopies, in which polyps are suspected in at least $35 \%$ of cases, continue warfarin at a decreased dose.

- If the likelihood of polypectomy is minor or equal to $1 \%$, continue with warfarin.

\section{WHAT ROLE DOES LOW MOLECULAR WEIGHT HEPARIN PLAY IN ANTICOAGULATON REVERSAL?}

In its recommendations, ASGE (4) provides management guidelines for low molecular weight heparin utilisation as a 
bridge for patients at high thrombotic risk. The difficulty is that there is neither an established dosage nor an ideal timing to reinitiate heparin, although it has been suggested that this time could vary from between 2 and 6 hours after the procedure, depending upon a joint consensus by the other specialists involved. Other authors propose decreasing LMWH doses prior to interventional procedures with an early reinitiation in high-risk patients as stated below, even though it is described in a trial for diagnostic catheterizations and not for procedures with a high risk of bleeding (31).

On the other hand, there are no conclusive data in the scientific literature to recommend the use of $L M W H$ as bridge therapy in patients treated with antiplatelet agents at high risk for thrombosis, even if it is routinely used in clinical practice (Table VI and Fig. 3).
The utilisation of low molecular weight heparin as bridge therapy is an appropriate guideline in patients at high-risk for thrombosis undergoing anticoagulant treatment, even though neither the guidelines nor the dosage have been defined as of yet.

\section{Recommendation D}

The utilisation of low molecular weight heparin as bridge therapy is a routine guideline in patients at high-risk for thrombosis undergoing antiplatelet treatment, even though it has not yet been confirmed by clinical studies.

\section{Recommendation E}

Table VI

\begin{tabular}{|c|c|c|c|c|c|c|c|c|c|}
\hline & -5 & -4 & -3 & -2 & -1 & 0 - TEST & 1 & 2 & 3 \\
\hline Kovacs (31) & Withdrawal antic. & & $\begin{array}{l}\mathrm{LMWH}, 200 \\
\mathrm{IU} / \mathrm{kg}\end{array}$ & $\begin{array}{c}\mathrm{LMWH}, 200 \\
\mathrm{IU} / \mathrm{kg}\end{array}$ & $\begin{array}{c}\text { INR }>1.4 \rightarrow \\
\text { Vit. K } 1 \mathrm{mg} \\
\mid \mathrm{NR}<1.4, \rightarrow \text { Suspend }\end{array}$ & $\begin{array}{c}\text { LMWH, } \\
100 \mathrm{lU} / \mathrm{kg}\end{array}$ & $\begin{array}{l}\mathrm{LMWH}, 200 \\
\mathrm{IU} / \mathrm{kg}\end{array}$ & $\begin{array}{c}\text { LMWH, } \\
200 \mathrm{lU} / \mathrm{kg}\end{array}$ & $\begin{array}{l}\text { LMWH, } \\
200 \mathrm{lU} / \mathrm{kg}\end{array}$ \\
\hline ASGE (4) & Suspend antic. & & LMWH & LMWH & LMWH & Do not prescribe & LMWH & LMWH & LMWH \\
\hline
\end{tabular}

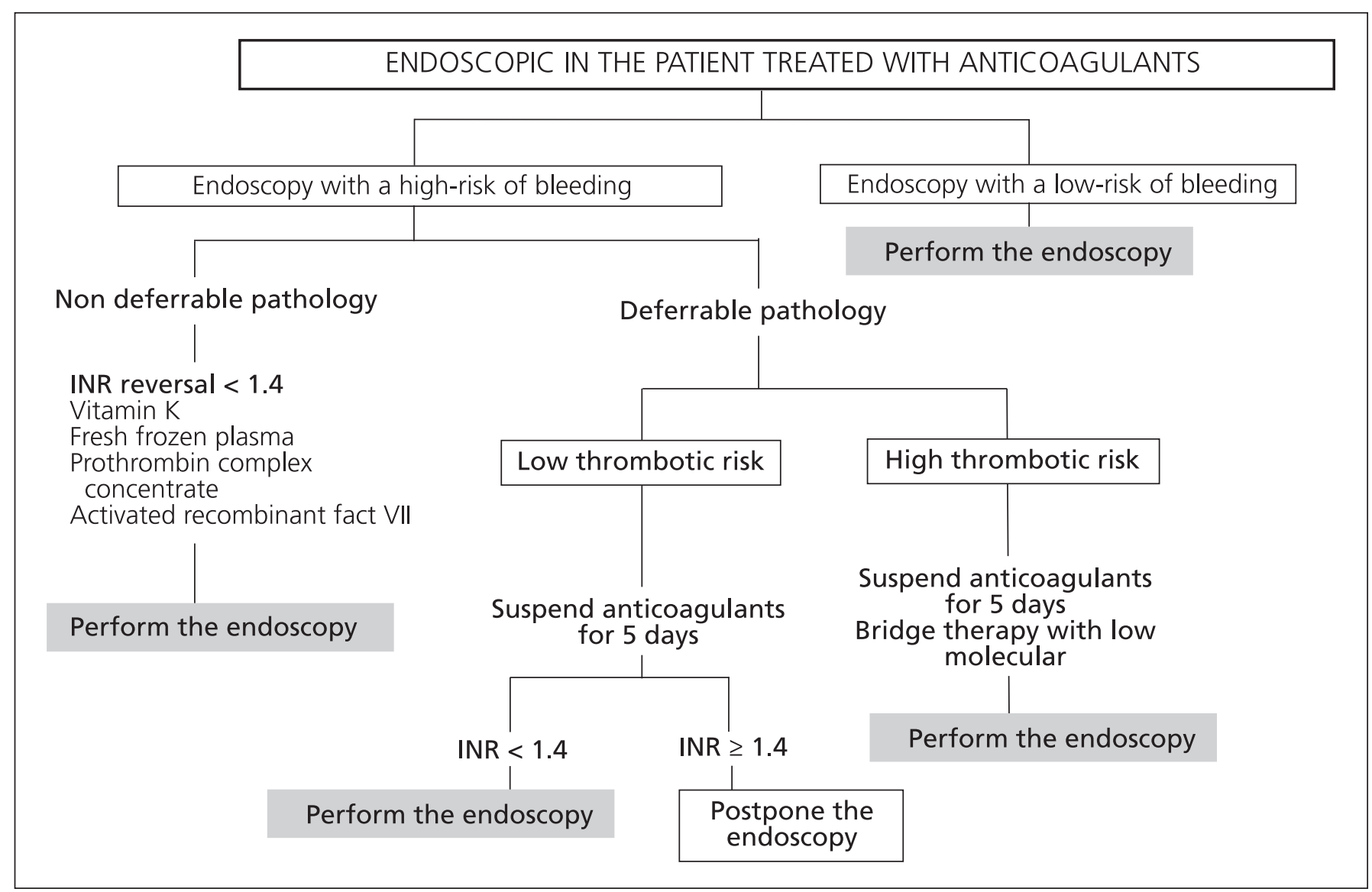

Fig. 3. 


\section{Annex I. Guideline for reversing anticoagulation or antiaggregation in patients undergoing gastrointestinal procedures PATIENT INFORMATION SHEET}

You are going to undergo an exploratory procedure, for therapeutic or diagnostic purposes on which was requested by Dr. after consultation in the Service.

Given that you are currently under treatment with the following medications

ing which may occur during this procedure. Hence, it is advisable to adjust the utilisation of these medications in order to decrease this risk.

In addition, you must not forget that you are taking these medications to avoid the formation of a blood clot. Therefore, any change in your treatment that may be necessary must be evaluated and scheduled by your physician.

\section{-PATIENTS BEING TREATED WITH ANTIPLATELET AGENTS}

1. Endoscopies or another technique having a low risk of bleeding will be performed (gastroscopies or colonoscopies with or without biopsies, uncomplicated polypectomies, echoendoscopy without puncture, FNA per ultrasound):

It is not necessary to suspend or adjust the dose of the drug.

If lesions that are susceptible to treatment (such as polyps) are found during the test, they can be resected if in the physician's medical judgement, he/she feels there is no high risk for bleeding.

2. Endoscopies or another technique having a high risk of bleeding will be performed (complex polypectomies, sphincterotomies and ERCP, dilatations, percutaneous endoscopic gastrostomy, echoendoscopy with puncture, varix treatment, balloon enteroscopy and liver biopsy):

$\square$ Patients with a high risk of thrombosis (non drug-eluting stents (1 month) and drug-eluting stents (18 months): attempt to defer the technique and if it is not possible, perform the technique with low molecular weight heparin according to the following guideline:

\begin{tabular}{|c|c|c|c|c|c|c|c|c|c|c|c|}
\hline$\overline{\text { Day }}$ & -7 & -6 & -5 & -4 & -3 & -2 & -1 & Test & +1 & +2 & \\
\hline Date & 11 & 11 & 11 & 11 & 11 & 11 & 11 & 11 & 11 & 11 & $1 /$ \\
\hline Anti-platelet agent & No & No & No & No & No & No & No & No & Yes & Yes & Yes \\
\hline Clexane $^{\circ} 60$ mg s.c. & No & $\begin{array}{l}\text { 9:00 a.m. } \\
\text { 9:00 p.m. }\end{array}$ & $\begin{array}{l}\text { 9:00 a.m. } \\
\text { 9:00 p.m. }\end{array}$ & $\begin{array}{l}\text { 9:00 a.m. } \\
\text { 9:00 p.m. }\end{array}$ & $\begin{array}{l}\text { 9:00 a.m. } \\
\text { 9:00 p.m. }\end{array}$ & $\begin{array}{l}\text { 9:00 a.m. } \\
\text { 9:00 p.m. }\end{array}$ & 9:00 a.m. & No & $\begin{array}{l}\text { 9:00 a.m. } \\
\text { 9:00 p.m. }\end{array}$ & $\begin{array}{l}\text { 9:00 p.m. } \\
\text { 9:00 a.m. }\end{array}$ & $\begin{array}{l}\text { 9:00 a.m. } \\
\text { 9:00 p.m. }\end{array}$ \\
\hline
\end{tabular}

$\square$ Patients with a low risk for thrombosis (TEP, uncomplicated MI R/T AF, aortic valvulopathy)

\begin{tabular}{|c|c|c|c|c|c|c|c|c|c|c|c|}
\hline Day & -7 & -6 & -5 & -4 & -3 & -2 & -1 & Test & +1 & +2 & \\
\hline$\overline{\text { Date }}$ & 11 & 11 & $1 /$ & 11 & 11 & $1 /$ & 11 & 11 & $1 /$ & $1 /$ & 11 \\
\hline Anti-platelet agent & No & No & No & No & No & No & No & No & Yes & Yes & Yes \\
\hline Clexane $^{\bullet} 40$ mg s.c. & No & $\begin{array}{l}\text { 9:00 a.m. } \\
\text { 9:00 p.m. }\end{array}$ & $\begin{array}{l}\text { 9:00 a.m. } \\
\text { 9:00 p.m. }\end{array}$ & $\begin{array}{l}\text { 9:00 a.m. } \\
\text { 9:00 p.m. }\end{array}$ & $\begin{array}{l}\text { 9:00 a.m. } \\
\text { 9:00 p.m. }\end{array}$ & $\begin{array}{l}\text { 9:00 a.m. } \\
\text { 9:00 p.m. }\end{array}$ & 9:00 a.m. & No & $\begin{array}{l}\text { 9:00 a.m. } \\
\text { 9:00 p.m. }\end{array}$ & $\begin{array}{l}\text { 9:00 p.m. } \\
\text { 9:00 a.m. }\end{array}$ & $\begin{array}{l}\text { 9:00 a.m. } \\
\text { 9:00 p.m. }\end{array}$ \\
\hline
\end{tabular}

The last dose of Clexane is scheduled for 24 hours before the test procedure (adjust this if the procedure takes place in the afternoon).

\section{-PATIENTS BEING TREATED WITH ANTICOAGULANT AGENTS (SYNTRON৫)}

1. Endoscopies or another technique having a low risk of bleeding will be performed (gastroscopies or colonoscopies with or without biopsies, diagnostic echoendoscopy): The endoscopy can be performed without risk, including the taking of biopsies.

However, if you want to be assured, Guideline 2 may be carried out in the corresponding group in case a potentially treatable polyp or other lesion is detected any you do not wish to repeat the procedure at another time.

2. Endoscopies or another technique having a high risk of bleeding will be performed (polypectomies, sphincterotomy and ERCP, dilatations, percutaneous endoscopic gastrostomy, echoendoscopy with puncture, varix treatment and enteroscopy).

- Patients with a high risk of thrombosis (MI R/T AF associated with valvulopathy, mechanical mitral valve prosthesis, mechanical valve prosthesis with prior thromboembolism, antiphospholipid syndrome and multiple prior thromboses).

\begin{tabular}{|c|c|c|c|c|c|c|c|c|}
\hline Day & -3 & -2 & -1 & Test & +1 & +2 & +3 & +4 \\
\hline Date & 11 & 11 & 11 & 11 & 11 & 11 & 11 & 11 \\
\hline Syntron ${ }^{\circ}$ & No & No & No & No & Prior dose & Prior dose & Prior dose & Prior dose \\
\hline Clexane $^{\bullet} 60$ mg s.c. & No & $\begin{array}{l}\text { 9:00 a.m. } \\
\text { 9:00 p.m. }\end{array}$ & 9:00 a.m. & No & $\begin{array}{l}\text { 9:00 a.m. } \\
\text { 9:00 p.m. }\end{array}$ & $\begin{array}{l}\text { 9:00 a.m. } \\
\text { 9:00 p.m. }\end{array}$ & $\begin{array}{l}\text { 9:00 a.m. } \\
\text { 1 p.m. }\end{array}$ & $\begin{array}{c}\text { 9:00 a.m. } \\
1 \text { p.m. }\end{array}$ \\
\hline
\end{tabular}

] Patients with a low risk for thrombosis (TEP, uncomplicated MI R/T AF, aortic valvulopathy).

\begin{tabular}{|c|c|c|c|c|c|c|c|c|}
\hline Day & -3 & -2 & -1 & Test & +1 & +2 & +3 & +4 \\
\hline Date & 11 & 11 & 11 & 11 & 11 & 11 & 11 & 11 \\
\hline Syntron $^{\circ}$ & No & No & No & No & Prior dose & Prior dose & Prior dose & Prior dose \\
\hline Clexane $^{\bullet} 40$ mg s.c. & No & $\begin{array}{l}\text { 9:00 a.m. } \\
\text { 9:00 p.m. }\end{array}$ & 9:00 a.m. & No & $\begin{array}{l}\text { 9:00 a.m. } \\
\text { 9:00 p.m. }\end{array}$ & $\begin{array}{l}\text { 9:00 a.m. } \\
\text { 9:00 p.m. }\end{array}$ & $\begin{array}{l}\text { 9:00 a.m. } \\
\text { 1 p.m. }\end{array}$ & $\begin{array}{c}\text { 9:00 a.m. } \\
1 \text { p.m. }\end{array}$ \\
\hline
\end{tabular}

The last dose of Clexane is scheduled for 24 hours before the test procedure (adjust this if the procedure takes place in the afternoon).

In those patients whose prior control was not acceptable, it is advisable that the dose adjustment take place in the Anticoagulation Consultation before scheduling the procedure.

\section{DETECTION OF PROBLEMS AFTER THE TEST PROCEDURE}

If any bleeding episode is suspected (blood in the stools or bloody emesis, foul-smelling black stools, or incidence of dizziness accompanied by low blood pressure as well as significant abdominal quadrant pain) go immediately to the Emergency Department of your Health Centre or if this is not possible, go to your Hospital Centre making sure you bring this Information Sheet with you as well as the results of the tests that were performed. 


\section{CONCLUSIONS}

There is probably a lack of sufficient evidence to make decisions and recommendations with absolute certainty in each of the present situations, hence each professional healthcare team must prepare their own standards based on existing data. In this sense, we are providing you with our work proposal (see annex at the conclusion of this document).

An investigative effort must be made to define specific scenarios, especially those regarding the utilisation of double antiplatelet agents, and bridge guidelines for low molecular weight heparin, including the appropriate dosage and timing to reinitiate anticoagulation.

In patients who have an increased risk for coagulation disorders, the endoscopic technique must be specifically clear and concise, and the use of all available tools enabling appropriate bleeding control must be recommended in an explicit manner, optimizing contributory mechanical and thermal means such as clips, sutures, argon, endoloops, etc.

\section{REFERENCES}

1. Ezekowitz MD. Anticoagulation Interruptus: Not Without Risk. Circulation 2004; 110: 1518-9.

2. Eisen, GM, Baron, TH, Dominitz, JA, et al. Guideline on the management of anticoagulation and antiplatelet therapy for endoscopic procedures. Gastrointest Endosc 2002; 55: 775.

3. Baker RI, Coaughlin PB, Gallus AS, Harper PL, Salem HH, Word EM; the Warfarin Reversal Consensos Group. Warfarin reversal: consensus guidelines, on behalf of the Australasian Society of Trombosis and Haemostasis. Medical Journal of Australia 2004; 181(9): 492-7.

4. Zuckerman, MJ, Hirota, WK, Adler, DG, et al. ASGE guideline: the management of low-molecular-weight heparin and nonaspirin antiplatelet agents for endoscopic procedures. Gastrointest Endosc 2005; 61(2): 189-94.

5. Gerson LB, Gage BF, Owens DK, Triadafilopoulos G. Effect and outcomes of the ASGE guidelines on the periendoscopic management of patients who take anticoagulants. Am J Gastroenterol 2000; 95(7): 1717-24.

6. Lobo B, Saperas E. Tratamiento de la hemorragia digestiva por ruptura de varices esofágicas. Disponible en: .http://www.prous.com/digest/protocolos/view_protocolo.asp?id_protocolo=18. 2004 Prous Ed.

7. Cukor B, Cryer BL. The risk of rebleeding after an index GI bleed in patients on anticoagulation (abstract DDW 2008) Gastrointest Endosc 2008; 67 (5): AB243.

8. ASGE. Guidelines for Clinical Aplication. Position statement on laboratory testing before ambulatory elective endoscopic procedures. Gastrointestinal Endoscopy 1999; 50(6): 906-9.

9. Parra-Blanco A, Kaminaga N, Kojima Y, et al. Hemoclipping for postpolypectomy and postbiopsy colonia bleeding. Gastrointest Endosc 2000; 51: 37-41.

10. Smith LE. Fiberoptic colonoscopy: complications of colonoscopy and polyupectomy. Dis Colon Rectum 1976; 19: 407-12.

11. Sieg A, Hachmoeller-Eisenbach U, Eisenbach T. Prospective evaluation of complications in outpatient GI endoscopy: a survey among German gastroenterologists. Gastrointest Endosc 2001; 53: 620-7.

12. Di Giorgio P, De Luca L, Calcagno G, Rivellini G, Mandato M, De Luca B. Detachable snare versus epinephrine injection in the prevention of postpolypectomy bleeding: a randomized and controlled study. Endoscopy 2004; 36: 860-3

13. Cotton PB, Lehman G, Vennes J et al. Endoscopic sphincterotomy complications and their management: an attempt at consensus. Gastorintest Endosc 1991; 37: 383-93.

14. Hui CK, Lai KC, Yuen MF, Wong WM, Lam SK, Lai CL. Does withholding aspirin for one week reduce the risk of post-sphinterotomy bleeding? Aliment Pharmacol Ther 2002; 16: 929-36.

15. Nelson DB, Freeman ML. Major haemorrhage from endoscopic sphincterotomy: risk factor analysis. J Clin Gastroenterol 1994; 19: 283-7.

16. Weinberg BM, Shindy W, Lo S. Dilatación esfinteriana endoscópica con balón (esfinteroplastia) versus esfinterotomía para los cálculos del conducto biliar común (Revisión Cochrane traducida). En: La Biblioteca Cochrane Plus, 2007 Número 4. Oxford: Update Software Ltd. Disponible en: http://www.update-software.com (Traducida de The Cochrane Library, 2007 Issue 4. Chichester, UK: John Wiley \& Sons, Ltd)

17. Mönkemüller K, Fry LC, Neumann H, Rickes S, Malfertheiner P. Diagnostic and therapeutic utility of double balloon endoscopy: experience with 225 procedures. Acta Gastroenterol Latinoam 2007; 37(4): 216-23.

18. Bason MD, Manzini L, Palmer RH. Effect of nabumetone and aspirin on colonia mucosal bleeding time. Aliment Pharmacol Ther 2001; 15: $539-42$

19. Nakajima H, Takami H, Yamagata K, Kariya K, Tamai Y, Nara H. Aspirin effects on colonia mucosal bleeding: implications for colonia biopsy and polypectomy. Dis Colon Rectum 1997; 40(12): 1484-8.

20. Llau JV, de Andrés J, Gomar C, Gómez A, Hidalgo F, Sahagún J, et al. Fármacos que alteran la hemostasia y técnicas regionales anestésicas: recomendaciones de seguridad. Foro de consenso. Rev Esp Anestesiol Reanima 2001; 48: 270-8.

21. Llau JV, de Andrés J, Gomar C, Gómez A, Hidalgo F, Torres LM. Fármacos que alteran la hemostasia y técnicas regionales anestésicas: recomendaciones de seguridad. Rev Esp Anestesiol Reanima 2004; 51: $137-42$.

22. Freeman M, Nelson D, Sherman S, Haber GB, Herman ME, Dorsher $\mathrm{PJ}$, et al. Complications of endoscopic biliary sphincterotomy. N Engl J Med 1996; 335: 909-18.

23. Shiffman ML, Farrel MT, Yee YS. Risk of bleeding alter endoscopic biopsy or polypectomy in patients taking aspirin or other NSAIDs. Gastrointestinal Endoscopy 1994; 40: 458-62.

24. Hui AJ, Wong RM, China JK, Hung LC, Chung SC, Sung JJ. Risk of colonoscopic polipectomy bleeding with anticoagulants and antiplatelet agents: analiysis of 1657 cases. Gastrointest Endosc 2004; 59: 44-8.

25. Yousfi M, Gostout CJ, Baron TH, et al. Postpolypectomy lower gastrointestinal bleeding: potencial role of aspirin. Am J Gastroenterol 2004; 99: 1785-9.

26. Kimchi NA, Broide E, Scapa E, Birkenfeld S. Antiplatelet therapy and the risk of bleeding induced by gastrointestinal endoscopic procedures. A systematic review of the literature and recommendations. Digestion 2007; 75(1): 36-45.

27. Fox KA, et al. Benefits and risks of the combination of clopidogrel and aspirin in patients undergoing surgical revascularization for nonST-elevation acute coronary syndrome: the clopidogrel in unestable angina to prevent recurrent ischemic events (CURE) trial. Circulation 2004; 110: 1202.

28. Diener HC, et al. Aspirin and clopidogrel compared with clopidogrel alone alter recent ischaemic stroke or transient ischaemic attack in high-risk patients (MATCH): randomised, double-blind, placebocontrolled trial. Lancet 2004; 364: 331.

29. Kamath PS. Gastroenterologic procedures in patients with disorders of hemostasis. Up to date. Available at: http://www.uptodate.com/ physicians/gasthepa_toclist.asp 2007

30. Morillas JD, Simón MA. Endoscopia: preparación, prevención y tratamiento de las complicaciones. En: Asociación Española de Gastroenterología. Tratamiento de las enfermedades gastroenterológicas. Ed. SCM; 2006.

31. Kovacs MJ, Kearon C, Rodger M, Anderson DR, Turpie AGG, Bates $\mathrm{SM}$, et al. Single-arm study of bridging therapy with low-molecularweight heparin for patients at risk of arterial embolism who require temporary interruption of warfarin. Circulation 2004; 110: 1658-63. 


\title{
Guía de práctica clínica para el manejo de la coagulación en pacientes sometidos a técnicas endoscópicas
}

\author{
F. Alberca de las Parras \\ Servicio de Aparato Digestivo. Hospital Virgen de la Arrixaca. Murcia
}

\section{¿POR QUÉ ELABORAR UNA GUÍA EN RELACIÓN CON LOS PROBLEMAS DE COAGULACIÓN Y LA REALIZACIÓN DE TÉCNICAS ENDOSCÓPICAS?}

Desde hace años la anticoagulación y la antiagregación simple o doble se han convertido en un arma terapéutica y preventiva sobre todo en patologías cardiovasculares de alta prevalencia. Esto, unido al aumento del intervencionismo en las técnicas endoscópicas, supone un incremento del riesgo.

Pero el riesgo no sólo procede de la potencial hemorragia, sino también de los riesgos trombóticos (1), no siendo razonable que los endoscopistas obviemos los mismos.

Es necesario realizar un esfuerzo para aunar criterios basándonos en la literatura publicada. Otras sociedades ya han iniciado este camino (2-4) y se han demostrado incluso beneficios secundarios tanto a ahorro económico como a un impacto nulo en la incidencia de trombosis al aplicar dichas guías (5).

\section{EN PACIENTES CON HEMORRAGIA DIGESTIVA, ¿QUÉ ACTITUD SE DEBE TOMAR ANTE EL USO DE ANTICOAGULANTES, ANTIAGREGANTES O AINE? (Fig. 1)}

Los anticoagulantes deben ser cesados inmediatamente y se pueden iniciar los siguientes métodos terapéuticos de forma secuencial y en paralelo a la técnica endoscópica $(3,6)$.

1. Vitamina $\mathrm{Kl}$ i.v. (fitomenadiona), $10 \mathrm{mg}$ (una ampolla) en $100 \mathrm{ml}$ de suero fisiológico o suero glucosado 5\%: $10 \mathrm{ml}$ en 10 minutos ( $1 \mathrm{mg} / 10 \mathrm{~min}$ ) y luego el resto en 30 minutos. Su efecto dura 8 horas aproximadamente y no es inmediato.

2. Plasma fresco, de 10 a $30 \mathrm{ml} / \mathrm{kg}$; a las 6 horas se puede repetir la mitad de la dosis, ya que la vida media de los factores es de 5 a 8 horas.

3. Concentrado de complejo protrombínico asociado a factor IX (Prothromplex Immuno TIM 4600 U.I ${ }^{\circledast}$ ): equi- vale a $500 \mathrm{ml}$ de plasma. Dosis: (tiempo de protrombina deseado - obtenido) $\mathrm{x}$ kg peso x 0,6 .

4. Factor VII recombinante activado: $80 \mu \mathrm{g} / \mathrm{kg}$ en bolus lento (amp. de $2 \mathrm{ml}=1,2 \mathrm{mg}$ ).

- Efecto a los 10 a 30 minutos de la administración.

- La duración del efecto es de 12 horas.

- No se debe asociar a los complejos protrombínicos.

- Normaliza el tiempo de protrombina y corrige los defectos de función plaquetar.

Se utilizarán estos mecanismos hasta que el INR se estabilice entre 1,5 y 2,5 y cese el sangrado. Los anticoagulantes se reiniciarán a las 3-5 días una vez nos hemos asegurado de que han disminuido los riesgos (realizar segundas endoscopias (second look).

Recientemente se ha presentado un abstract que demuestra que el riesgo de sangrado en pacientes que toman antiacoagulantes es de 6,5 veces mayor que los que no lo toman (7).

La suspensión de los antiagregantes y los AINE no va a cambiar la historia natural pues su efecto sobre la coagulación se va a retrasar algunos días, aunque se debe tener en cuenta si estamos ante lesiones que previsiblemente no van a cicatrizar con rapidez. No se debe olvidar que la aspirina y los AINE pueden ser así mismo la causa de la hemorragia.

\section{¿SE DEBEN REALIZAR PRUEBAS DE COAGULACIÓN PREVIAS A LA REALIZACIÓN DE TÉCNICAS ENDOSCÓPICAS?}

No existe evidencia científica en este sentido. En una guía clínica publicada por la Asociación Americana de Endoscopia Digestiva (ASGE) (8) establece que ni siquiera para técnicas de alto riesgo es útil la realización de pruebas de laboratorio para detectar alteraciones ocultas de la coagulación, no considerándolas indicadas; además plantea que legalmente es más peligrosa la mala interpretación de una alteración de coagulación que el no haber realizado las pruebas. Los test nunca pueden sustituir una historia clínica previa y sólo es obligado hacerlos ante la sospecha de alteraciones. 


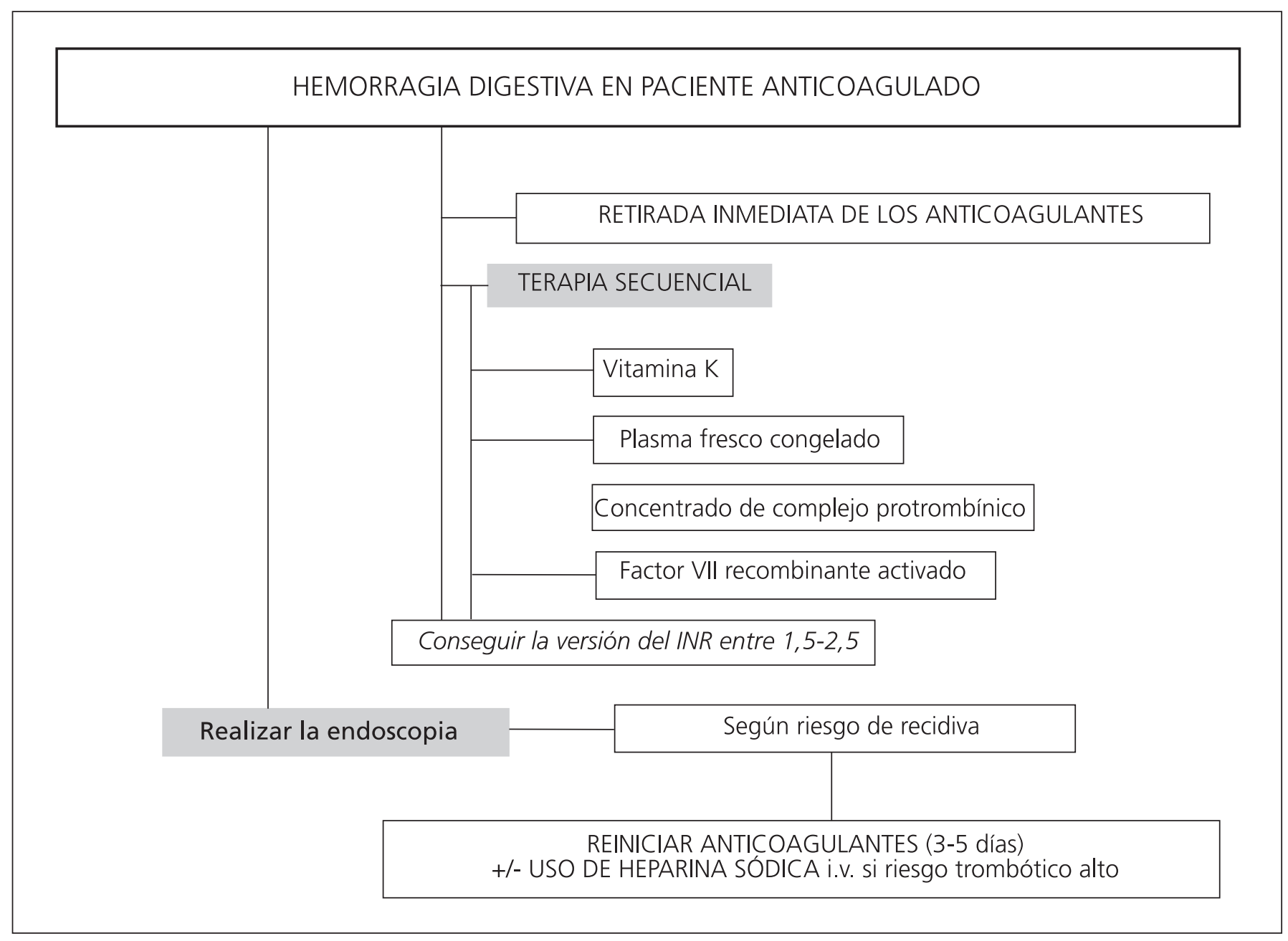

Fig. 1.

\section{¿QUÉ ALTERACIONES EN LA COAGULACIÓN DEBEN TENERSE EN CUENTA ANTE LA REALIZACIÓN DE TÉCNICAS ENDOSCÓPICAS?}

En los pacientes que presentan trombocitopenia la actitud depende del tipo de procedimiento.

- En los procedimientos de riesgo alto es necesario que la cifra de plaquetas sea superior a 50.000/ $\mu$ l.

- Las exploraciones endoscópicas de bajo riesgo se pueden realizar en pacientes con plaquetas $>20.000 / \mu 1$.

\section{Recomendación D}

-Actividad de protrombina: cifras de TP menor de $50 \%$ $v s$. INR $>1,5$ suponen un aumento del riesgo de sangrado. Se encuentra de forma habitual en las hepatopatías crónicas, así como el uso de anticoagulantes orales (Tabla I).

- Alteración del tiempo de tromboplastina parcial activado (PTTA): se mide como una prolongación del PTTA respecto al PTTA tr. Se puede ver en el uso de heparina sódica i.v.
Tabla I

\begin{tabular}{llll}
\hline Agente & $\begin{array}{l}\text { Normalización } \\
\text { de la hemostasia }\end{array}$ & T. Prot/INR & PTTA \\
\hline Antiagregantes & 2-10 días* & Normal & Normal \\
\hline AlNE** & $1-3$ días & Normal & Normal \\
\hline Heparina sódica i.v. & 2-4 horas & Alargado $(+)$ & Alargado $(+++)$ \\
\hline Heparina BPM & Al menos 12 horas & Normal & Normal \\
\hline Anticoagulantes orales & $4-6$ días & Alargado $(+++)$ & Alargado $(+)$ \\
\hline *En página 4; **En página 4. & &
\end{tabular}

\section{¿CÓMO SE PUEDEN CORREGIR ESTAS ALTERACIONES PREVIAMENTE A LA REALIZACIÓN DE TÉCNICAS ENDOSCÓPICAS?}

- La corrección de déficit de plaquetas se realiza de forma programada, infundiendo durante la técnica endoscópica y en el tramo previo inmediato. Es sufi- 
ciente elevar la cuenta de plaquetas entre 40.000 a $50.000 / \mathrm{mm}^{3}$.

- Cada unidad de plaquetas aumenta el recuento en 5.000 a 10.000 por $\mathrm{mm}^{3}$.

- La dosis es de $1 \mathrm{U} / 10 \mathrm{~kg}$ de peso.

- En caso de refractariedad a plaquetas con manifestaciones de sangrado grave se recomienda factor VIl activado recombinante (rVlla) (Novoseven ${ }^{\odot}$ ) con efecto hemostático en pacientes con trombocitopenia grave y trombocitopatías, a una dosis de 90 a $150 \mu \mathrm{g} / \mathrm{kg}$ cada dos horas por vía intravenosa, hasta controlar el sangrado. Por su alto precio el uso profiláctico debe ser limitado a casos muy concretos y urgentes.

- En el caso de alteraciones del tiempo de protrombi$n a$ se aplican las mismas pautas comentadas en pacientes anticoagulados.

- Las alteraciones del tiempo de tromboplastina parcial activado (PTTA), como por ejemplo en pacientes en tratamiento con heparina sódica, suelen revertir al retirar la misma en el plazo de 4 a 6 horas. Sin embargo, si queremos por situación de urgencia una reversión más rápida, se utilizará el sulfato de protamina: $1 \mathrm{mg}$ neutraliza 100 unidades de heparina. Administración lenta en 100 $\mathrm{ml}$ de suero fisiológico. No administrar una dosis superior a $100 \mathrm{mg}$ ( 2 ampollas), ya que dosis altas pueden producir efecto anticoagulante.

\section{¿QUÉ TÉCNICAS ENDOSCÓPICAS SE CONSIDERAN DE MAYOR RIESGO DE SANGRADO?}

El riesgo de sangrado parece definido por consenso, y así se establece en las diferentes guías clínicas (2) y manuales, planteando dos niveles de riesgo (Tabla II).

-Biopsias: el riesgo de hemorragia en biopsias es de aproximadamente el $1 \%$ o (9).

-Polipectomía: el riesgo de sangrado mayor de la polipectomía en varias series amplias oscila entre el 0,05 y el $1 \%$, si bien puede ser de hasta el $4,3 \%$ en pólipos mayores de $1 \mathrm{~cm}$ y del 6,7\% en mayores de $2 \mathrm{~cm}(10-12)$. Parece ser que dicho riesgo se aumenta con el tamaño mayor de $2 \mathrm{~cm}$ de los pólipos y se ha detectado que san-

Tabla II

\begin{tabular}{ll}
\hline Bajo riesgo de sangrado $(<1 \%)$ & Alto riesgo de sangrado (1-6\%) \\
\hline Endoscopia diagnóstica con o sin biopsia & Polipectomía \\
Colangiopancreatografía retrógrada & Coagulación y ablación con láser \\
endoscópica diagnóstica (CPRE) & Esfinterotomía \\
Inserción de stents biliares sin & Dilatación estenosis benignas o malignas \\
esfinterotomía & Gastrostomía endoscópica percutánea \\
Ecoendoscopia & EUS-PAAF \\
Enteroscopia de pulsión & Tratamiento de varices \\
& Enteroscopia con balón \\
\hline
\end{tabular}

gran más los pediculados que los sesiles, por lo que en pacientes en tratamiento antiagregante es aconsejable asociar a una técnica que disminuya el riesgo como el uso de adrenalina profiláctica, el endoloop o lazo desechable y los endoclips (11).

- Inmediato, cuando no se coagulan bien los vasos nutricios.

- Tardío, entre 1 y 14 días, más grave; se debe tener en cuenta antes de reintroducir los antiagregantes.

-CPRE y esfinterotomía: la incidencia de hemorragia se sitúa entre el 2,5 y el $5 \%$ (13). Los diferentes estudios definen la anticoagulación como claro factor de riesgo para el sangrado. Con respecto a la antiagregación sólo dos estudios retrospectivos $(14,15)$ han analizado dicho efecto, con resultados no concluyentes como se plantea en la Guía Clínica de la Sociedad Americana, pero con un riesgo para el sangrado agudo en uno de ellos (14) del 9,7 vs. 3,9\% (AAS vs. control, $\mathrm{p}<0,001)$ y para el sangrado diferido del 6,5 vs. 2,7\% ( $\mathrm{p}=0,04)$, lo cual sugiere que salvo en situaciones de urgencia es deseable la retirada al menos 7 días antes de la técnica. La esfinteroplastia con balón se ha propuesto como una técnica alternativa en pacientes con necesidad de apertura urgente de la vía biliar y con alteraciones de la coagulación (16), así como el uso de prótesis biliares sin esfinterotomía de forma transitoria.

-Enteroscopia: la técnica simple no parece suponer un riesgo, pero si se plantea como técnica terapéutica e intervencionista se debe enfocar como una técnica de riesgo, ya que hasta en el 64\% de los casos se realiza terapéutica (17).

\section{¿ES LA ANTIAGREGACIÓN, SIMPLE O DOBLE, UNA CONTRAINDICACIÓN PARA ALGUNA TÉCNICA ENDOSCÓPICA?}

No existen datos convincentes que conviertan la antiagregación simple en una contraindicación absoluta para ninguna técnica endoscópica.

En cuanto a la antiagregación doble no hay trabajos que analicen su efecto, aunque parece razonable con los datos existentes, el intentar evitar realizar intervencionismo mientras sea necesario su uso, o bien plantearse proteger con heparina de bajo peso molecular.

\section{¿EXISTE EVIDENCIA ACERCA DEL AUMENTO DEL SANGRADO INTESTINAL EN PACIENTES ANTIAGREGADOS?}

En un estudio en animales de experimentación al realizar lesiones de $7 \mathrm{~mm}$ en colon, se demostró un aumento del tiempo de sangrado en los tratados con aspirina frente a los no tratados (155 vs. 169 segundos $-\mathrm{p}<0,05)(18)$; así mismo se ha encontrado un aumento del sangrado en los puntos de biopsia en pacientes tratados con aspirina frente a aquellos controles o con AINE (19). 
Sin embargo estos estudios experimentales no han encontrado traducción clínica en la literatura cuando se trata de su aplicación en pacientes sometidos a técnicas endoscópicas.

La Sociedad Española de Anestesiología y Reanimación ha elaborado dos recomendaciones de consenso ante la realización de anestesia locorregional y epidural con los siguientes datos $(20,21)$ (Tablas III y IV).

Tabla III. Tiempo de seguridad de antiagregantes

\begin{tabular}{|c|c|}
\hline $10 \mathrm{~d}$ & Ticlopidina (Tiklid ${ }^{\ominus}$, Ticlodone ${ }^{\ominus}$, Ticlopidina EFG${ }^{\ominus}$ ) \\
\hline \multirow[t]{2}{*}{$7 \mathrm{~d}$} & Clopidogrel (Iscover ${ }^{\bullet}$, Plavixe) \\
\hline & 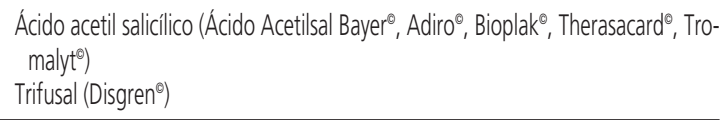 \\
\hline $1 \mathrm{~d}$ & $\begin{array}{l}\left.\text { Dipiridamol (Persantin }{ }^{\circ}\right) \\
\left.\text { Tirofiban (Aggrastat }{ }^{\circ}\right)\end{array}$ \\
\hline
\end{tabular}

Tabla IV. Actividad antiagregante de los AINE

\begin{tabular}{ll}
\hline Importante (7 d.): & Aspirina, Piroxicam, Tenoxicam, Indometacina, Ketorolaco \\
\hline Débil (12 h.): & $\begin{array}{l}\text { Meloxicam, Sulindac, Nabumetona, Diflunisal, Paracetamol, Dipiro- } \\
\text { na, Flurbiprofeno }\end{array}$ \\
\hline Nulo (0 d.): & Coxibs \\
\hline
\end{tabular}

- La aspirina y los AINE no han demostrado en varios trabajos que aumenten el riesgo de sangrado ante polipectomías, aunque se trata de estudios retrospectivos o limitados en su análisis y fueron la base para la guía clínica de la ASGE, la cual no recomienda la retirada de los antiagregantes previa a las técnicas endoscópicas $(13,22-24)$.

Sin embargo, uno de los estudios, prospectivo (22), aunque no presenta un aumento de las complicaciones sí muestra trazas de sangrado en heces hasta en un $6,3 \%$ de los pacientes frente a un 2,1\% en los placebos. Se ha analizado específicamente la complicación más importante, que es el sangrado tardío en un estudio de casos control (25), confirmando que no existe un aumento del sangrado en el subgrupo que toma aspirina frente al placebo, pero no se analizó el uso de aspirina más allá de 3 días después de la técnica, existiendo episodios de sangrado en diferentes técnicas hasta 19 días después, por lo que el análisis es al menos dudoso.

En esfinterotomías, como ya se ha comentado, sólo existen dos estudios que analizan su efecto, si bien también con limitaciones para su interpretación. Por ello, algunos autores (26) recomiendan la retirada de los antiagregantes de 4 a 7 días antes de las técnicas de riesgo y su reintroducción a los 7 días si se ha puesto por prevención secundaria $o$, si se trata de prevención primaria, a los 10 días tras esfinterotomía o a los 14 tras polipectomía.
Para pruebas de alto riesgo de sangrado se ha definido que se debe retirar el clopidogrel 5 días antes en pacientes con doble antiagregación (27).

\section{¿QUÉ PATOLOGÍAS TIENEN UN MAYOR RIESGO TROMBÓTICO ANTE LA REVERSIÓN DE LA ANTIAGREGACIÓN?}

-Stents coronarios: la suspensión de la doble antiagregación (aspirina + clopidogrel) precozmente tiene un riesgo de trombosis del stent del 29\% (8-30\%) (Fig. 2):

- Stents no recubiertos: mantener 1 mes.

- Stents recubiertos (liberador de antiproliferativos): mantener 1 año (o 18 meses).

- Prevención secundaria (tras IAM reciente): no tiene ventajas la asociación AAS + clopidogrel frente a clopidogrel sólo (28).

-Prevención primaria de cardiopatía en pacientes de riesgo: no precisan doble antiagregación.

- Tras artroplastia de cadera o rodilla o cirugía por fractura de cadera: el riesgo está aumentado en 10 a 35 días, recomendándose prevención con HBPM o flondaparinux.

En todos los casos lo deseable es retrasar la terapéutica hasta que el riesgo trombótico sea el menor posible; en los casos de doble antiagregación es posible suspender el clopidogrel 7 días antes y mantener la aspirina según la pauta prevista, o bien proteger con heparina de bajo peso molecular.

\section{¿ES LA ANTICOAGULACIÓN UNA CONTRAINDICACIÓN PARA ALGUNA TÉCNICA ENDOSCÓPICA?}

- Sí, para las técnicas endoscópicas de alto riesgo de sangrado.

- En casos urgentes se puede plantear realizar dichas técnicas tras revertir la anticoagulación (vitamina K, plasma fresco o factores de la protrombina) hasta conseguir un $\mathrm{INR} \leq 1,4$.

\section{¿QUÉ PATOLOGÍAS TIENEN UN MAYOR RIESGO TROMBÓTICO ANTE LA REVERSIÓN DE LA ANTICOAGULACIÓN?}

La ASGE (2) define el riesgo de trombosis en dos grados que han sido asumidos de forma generalizada por otros autores, en manuales (29) y en revisiones (30), no existiendo en la literatura actual datos en otro sentido (Tabla V): 


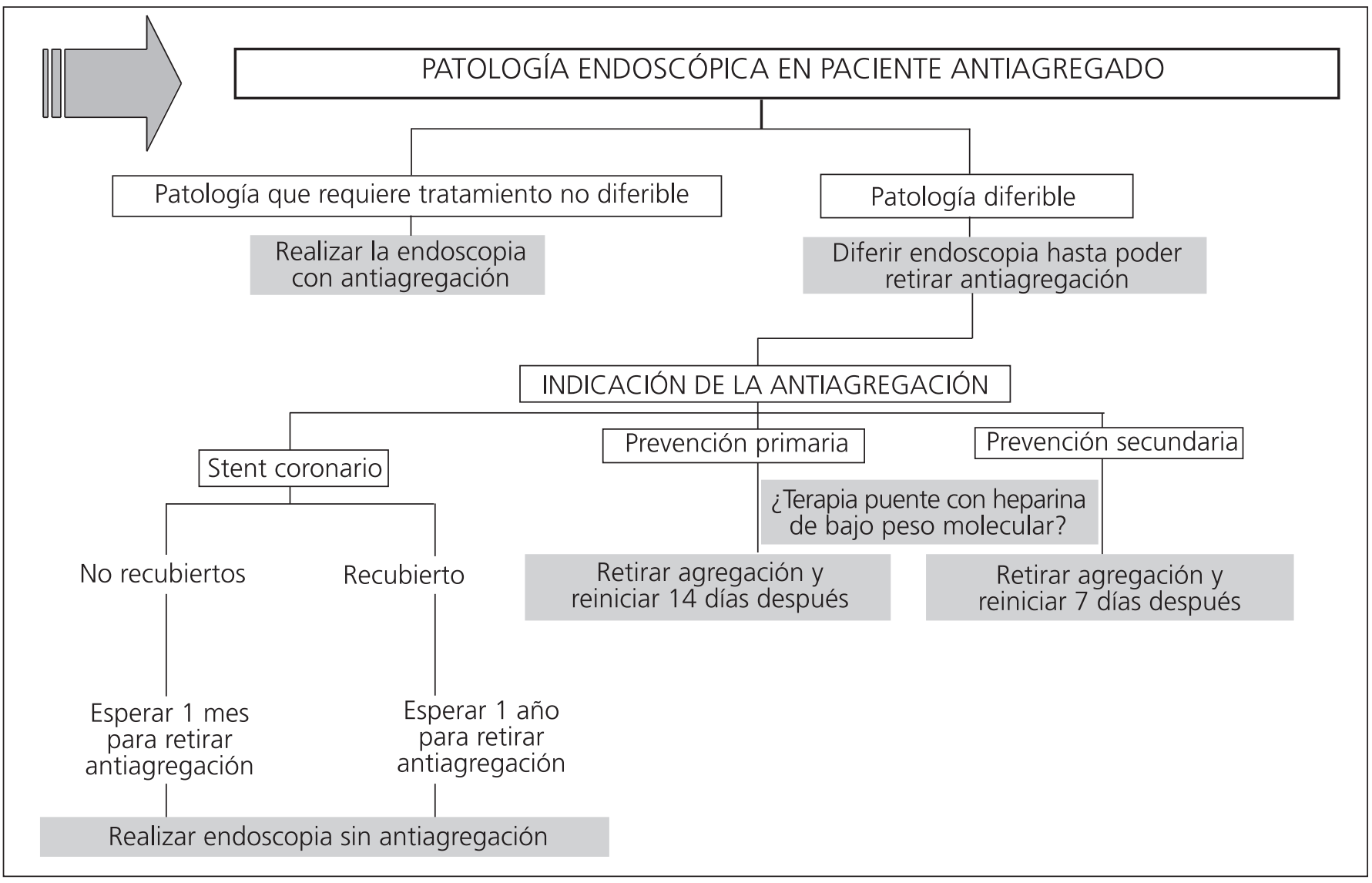

Fig. 2.

Tabla V

\begin{tabular}{ll}
\hline $\begin{array}{l}\text { Riesgo bajo (1-2\% si se interrumpe la } \\
\text { anticoagulación de } 4 \text { a } 7 \text { días) }\end{array}$ & Riesgo alto \\
\hline Trombosis venosa profunda & AC x FA con enfermedad valvular \\
AC x FA paroxística o crónica no & Prótesis mitral metálica \\
complicada con patología valvular & Válvula metálica con episodio trombótico \\
Prótesis valvular biológica & previo \\
Prótesis aórtica metálica &
\end{tabular}

\section{¿CUÁL SERÁ LA PAUTA PRÁCTICA PARA LA REVERSIÓN DE LA ANTICOAGULACIÓN? (Fig. 3)}

En un análisis de decisión basado en la aplicación de las guías clínicas de la ASGE (5) se definieron como las estrategias más coste-efectivas las siguientes:

- En pacientes de riesgo trombótico bajo (por ejemplo, fibrilación auricular sin patología valvular) o si la posibilidad de polipectomía excede el $60 \%$, cesar la warfarina 5 días antes.

- En colonoscopias de screening en las que se espera encontrar pólipos en al menos un 35\% de los casos, mantener la warfarina con reducción de dosis.

- Si la posibilidad de polipectomía es menor o igual al $1 \%$, continuar con warfarina.

\section{¿CUÁl SERÁ EL PAPEL DE LA HEPARINA DE BAJO PESO MOLECULAR EN LA REVERSIÓN DE LA ANTICOAGULACIÓN?}

En sus recomendaciones, la ASGE (4) plantea una pauta de manejo con el uso de heparina de bajo peso molecular como puente en pacientes de alto riesgo trombótico; el problema es que no se han definido ni las dosis ni cuál es el momento ideal para la reintroducción de la heparina, aunque se plantea que puede oscilar entre las 2 y las 6 horas tras el procedimiento, debiendo consensuarse con otros especialistas implicados. Otros autores proponen reducción de dosis de la HBPM previo a procedimientos intervencionistas, con reintroducción precoz en pacientes de alto riesgo según la siguiente, aunque está descrita en un ensayo para cateterismos diagnósticos y no para técnicas de alto riesgo de sangrado (31).

Por otro lado faltan datos concluyentes en la literatura para aconsejar el uso de HBPM como terapia puente en pacientes en tratamiento antiagregante y con alto riesgo trombogénico, si bien su uso es habitual en la práctica clínica (Tabla VI y Fig. 3).

El uso de heparina de bajo peso molecular como método puente es una pauta aceptable en pacientes anticoagulados con alto riesgo trombótico, aunque no se han definido las pautas ni las dosis.

\section{Recomendación D}


Tabla VI

\begin{tabular}{|c|c|c|c|c|c|c|c|c|c|}
\hline & -5 & -4 & -3 & -2 & -1 & 0 - PRUEBA & 1 & 2 & 3 \\
\hline Kovacs (31) & Suspender anticoag. & & $\begin{array}{c}\mathrm{HBPM}, 200 \\
\mathrm{IU} / \mathrm{kg}\end{array}$ & $\begin{array}{c}\mathrm{HBPM}, 200 \\
\text { IU/kg }\end{array}$ & $\begin{array}{c}\text { INR }>1.4 \rightarrow \\
\text { Vit. K } 1 \text { mg } \\
\text { INR }<1,4 \rightarrow \text { suspender }\end{array}$ & $\begin{array}{c}\text { HBPM, } \\
100 \mathrm{lU} / \mathrm{kg}\end{array}$ & $\begin{array}{c}\text { HBPM, } 200 \\
\mathrm{IU} / \mathrm{kg}\end{array}$ & $\begin{array}{c}\text { HBPM, } \\
200 \mathrm{IU} / \mathrm{kg}\end{array}$ & $\begin{array}{c}\mathrm{HBPM}, \\
200 \mathrm{IU} / \mathrm{kg}\end{array}$ \\
\hline ASGE (4) & Suspender anticoag. & & HBPM & HBPM & HBPM & No poner & HBPM & HBPM & HBPM \\
\hline
\end{tabular}

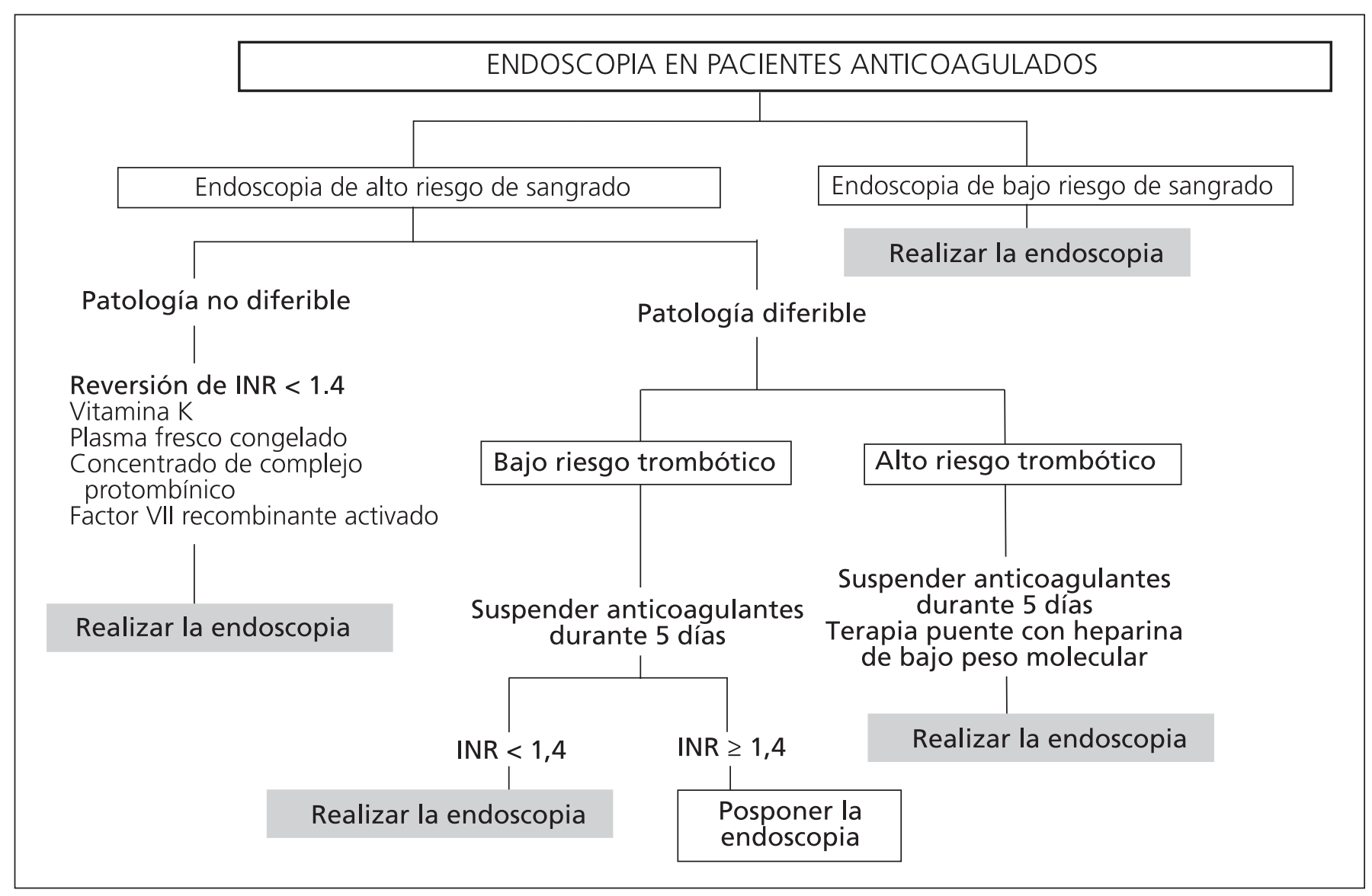

Fig. 3.

El uso de heparina de bajo peso molecular como método puente es una pauta habitual en pacientes antiagregados con alto riesgo trombótico, aunque no se avala por ensayos clínicos.

\section{Recomendación $\mathrm{E}$}

\section{CONCLUSIONES}

Probablemente falta evidencia suficiente para tomar decisiones y hacer recomendaciones de forma absoluta en cada una de las situaciones planteables, por lo que cada equipo debe elaborar sus propias normas basándose en los datos existentes. En este sentido nosotros aportamos nuestra propuesta de trabajo (ver anexo al final).

Es necesario realizar un esfuerzo investigador para definir escenarios concretos, siendo necesario realizarlo sobre todo en relación al uso de la doble antiagregación y de las pautas puente con heparina de bajo peso molecular y que definan dosis y momentos del reinicio de la anticoagulación.

En los pacientes con riesgo aumentado por tener alteraciones de la coagulación la técnica endoscópica debe ser más depurada y se debe recomendar de forma explícita el uso de todas aquellas herramientas que nos permitan controlar el sangrado, potenciando medios mecánicos y térmicos coadyuvantes como clips, suturas, argón, endoloops, etc. 


\section{Anexo 1. Guía para la reversión de anticoagulación o antiagregación en pacientes sometidos a técnicas digestivas}

\section{INFORMACIÓN PARA EL PACIENTE}

Usted se va a someter a una exploración,

con intención terapéutica o diagnóstica el día

y solicitada por el Dr/a.

en la Consulta de

Dado que está usted en tratamiento con los siguientes fármacos

meterse a dicha técnica, por lo que es conveniente ajustar su uso para disminuir dicho riesgo.

existe un riesgo aumentado de sangrado al so-

Por otro lado no hay que olvidar que usted toma estos fármacos para evitar la formación de una trombosis, por lo que el ajuste que se debe realizar debe ser evaluado y programado por su médico.

\section{-PACIENTES EN TRATAMIENTO CON ANTIAGREGANTES}

1. Se va a realizar endoscopias o técnicas con bajo riesgo de sangrado (gastroscopias o colonoscopias con o sin biopsia, polipectomías simples, ecoendoscopia sin punción, PAAF por ecografía):

No es necesario suspender el fármaco ni ajustar la dosis.

- Si durante la prueba se encontrasen lesiones que fuesen susceptibles de tratamiento (como pólipos) podrían ser extirpados si a juicio del médico no fuesen de alto riesgo de sangrado.

2. Se van a realizar endoscopias o técnicas con alto riesgo de sangrado (polipectomías complejas, esfinterotomía y CPRE, dilataciones, gastrostomía endoscópica percutánea, ecoendoscopia con punción, tratamiento de varices, enteroscopia con balón, biopsia hepática).

( Pacientes con alto riesgo de trombosis. Stents no recubiertos (1 mes) y stents recubiertos (18 meses): intentar diferir la técnica, y si no es posible, realizarla con heparina de bajo peso molecular $\left(\right.$ Clexane $\left.^{\circ}\right)$ según la siguiente pauta:

\begin{tabular}{|c|c|c|c|c|c|c|c|c|c|c|c|}
\hline$\overline{\text { Día }}$ & -7 & -6 & -5 & -4 & -3 & -2 & -1 & Prueba & +1 & +2 & \\
\hline Fecha & 11 & $1 /$ & 11 & 11 & $1 /$ & 11 & $1 /$ & 11 & 11 & 11 & $1 /$ \\
\hline Antiagregante & No & No & No & No & No & No & No & No & Sí & Sí & Sí \\
\hline Clexane $^{\circ} 60$ mg s.c. & No & $\begin{array}{c}9 \mathrm{~h} \\
21 \mathrm{~h}\end{array}$ & $\begin{array}{l}9 \mathrm{~h} \\
21 \mathrm{~h}\end{array}$ & $\begin{array}{c}9 \mathrm{~h} \\
21 \mathrm{~h}\end{array}$ & $\begin{array}{c}9 \mathrm{~h} \\
21 \mathrm{~h}\end{array}$ & $\begin{array}{c}9 \mathrm{~h} \\
21 \mathrm{~h}\end{array}$ & $9 \mathrm{~h}$ & No & $\begin{array}{c}9 \mathrm{~h} \\
21 \mathrm{~h}\end{array}$ & $\begin{array}{c}9 \mathrm{~h} \\
21 \mathrm{~h}\end{array}$ & $\begin{array}{c}9 \mathrm{~h} \\
21 \mathrm{~h}\end{array}$ \\
\hline
\end{tabular}

\begin{tabular}{|c|c|c|c|c|c|c|c|c|c|c|c|}
\hline Día & -7 & -6 & -5 & -4 & -3 & -2 & -1 & Prueba & +1 & +2 & \\
\hline Fecha & 11 & $1 /$ & 11 & $1 /$ & 11 & $1 /$ & 11 & $1 /$ & $1 /$ & $1 /$ & $1 /$ \\
\hline Antiagregante & No & No & No & No & No & No & No & No & Sí & Sí & Sí \\
\hline Clexane $^{\bullet} 40$ mg s.c. & No & $\begin{array}{c}9 \mathrm{~h} \\
21 \mathrm{~h}\end{array}$ & $\begin{array}{l}9 \mathrm{~h} \\
21 \mathrm{~h}\end{array}$ & $\begin{array}{l}9 \mathrm{~h} \\
21 \mathrm{~h}\end{array}$ & $\begin{array}{c}9 \mathrm{~h} \\
21 \mathrm{~h}\end{array}$ & $\begin{array}{c}9 \mathrm{~h} \\
21 \mathrm{~h}\end{array}$ & $9 \mathrm{~h}$ & No & $\begin{array}{c}9 \mathrm{~h} \\
21 \mathrm{~h}\end{array}$ & $\begin{array}{c}9 \mathrm{~h} \\
21 \mathrm{~h}\end{array}$ & $\begin{array}{c}9 \mathrm{~h} \\
21 \mathrm{~h}\end{array}$ \\
\hline
\end{tabular}

La última dosis de Clexane se pondrá 24 horas antes de la prueba (ajustar si se cita por la tarde)

\section{-PACIENTES EN TRATAMIENTO CON ANTICOAGULANTES (SINTRON)}

1. Se va a realizar endoscopias con bajo riesgo de sangrado (gastroscopias o colonoscopías con o sin biopsia, ecoendoscopia diagnóstica): la endoscopia se puede realizar sin riesgo, e incluso la toma de biopsias.

Sin embargo, si quiere asegurarse, puede realizar la pauta 2, en el grupo que le corresponda, por si durante a prueba se detectase un pólipo u otra lesión potencialmente tratable y no quisiese repetírsela en otra ocasión.

2. Se va a realizar endoscopias con alto riesgo de sangrado (polipectomía, esfinterotomía y CPRE, dilataciones, gastrostomía endoscópica percutánea, ecoendoscopia con punción, tratamiento de varices, enteroscopia).

] Pacientes con alto riesgo de trombosis (AC x FA asociada a valvulopatía, prótesis mitral mecánica, válvula mecánica con tromboembolismo previo, síndrome antifosfolípido, trombosis previas múltiples).

\begin{tabular}{|c|c|c|c|c|c|c|c|c|}
\hline$\overline{\text { Día }}$ & -3 & -2 & -1 & Prueba & +1 & +2 & +3 & +4 \\
\hline Fecha & 11 & $1 /$ & $1 /$ & $1 /$ & 11 & $1 /$ & $1 /$ & 11 \\
\hline Sintron $^{\circ}$ & No & No & No & No & Dosis previa & Dosis previa & Dosis previa & Dosis previa \\
\hline Clexane ${ }^{\ominus} 60$ mg s.c. & No & $\begin{array}{c}9 \mathrm{~h} \\
21 \mathrm{~h}\end{array}$ & $9 \mathrm{~h}$ & No & $\begin{array}{c}9 \mathrm{~h} \\
21 \mathrm{~h}\end{array}$ & $\begin{array}{c}9 \mathrm{~h} \\
21 \mathrm{~h}\end{array}$ & $\begin{array}{l}9 \mathrm{~h} \\
1 \mathrm{~h}\end{array}$ & $\begin{array}{l}9 \mathrm{~h} \\
1 \mathrm{~h}\end{array}$ \\
\hline
\end{tabular}

La última dosis de Clexane se pondrá 24 horas antes de la prueba (ajustar si se cita por la tarde).

En aquellos pacientes que tuviesen un mal control previo se aconseja el ajuste en la Consulta de Anticoagulación previa concertación de cita.

\section{DETECCIÓN DE PROBLEMAS TRAS LA PRUEBA}

Ante la sospecha de cualquier episodio de sangrado (sangre en las heces o en el vómito, heces negras malolientes o episodios de mareos mantenidos con tensión baja, así como cuadros de dolor abdominal importante), acudir a Urgencias de su Centro de Salud o en su defecto de su Centro Hospitalario, aportando tanto esta hoja como los resultados de las pruebas realizadas.

Fecha:

Fdo: Dr/a. 